The Viral Network 


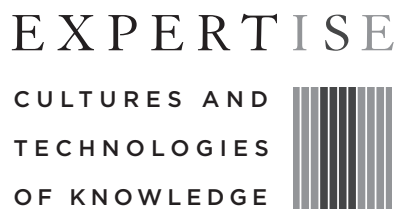

EDITED BY DOMINIC BOYER

A list of titles in this series is available at www.cornellpress.cornell.edu. 


\title{
The Viral Network
}

\author{
A Pathography of the H1N1 \\ Influenza Pandemic
}

Theresa MacPhail

Cornell University Press

ITHACA AND LONDON 


\section{Copyright $\odot 2014$ by Cornell University}

All rights reserved. Except for brief quotations in a review, this book, or parts thereof, must not be reproduced in any form without permission in writing from the publisher. For information, address Cornell University Press, Sage House, 512 East State Street, Ithaca, New York 14850.

First published 2014 by Cornell University Press

First printing, Cornell Paperbacks, 2014

Printed in the United States of America

\section{Library of Congress Cataloging-in-Publication Data}

MacPhail, Theresa, 1972- author.

The viral network : a pathography of the H1N1 influenza pandemic/ Theresa MacPhail.

$$
\text { pages } \mathrm{cm} \text {. - (Expertise) }
$$

Includes bibliographical references (p. ).

ISBN 978-0-8014-5240-6 (cloth : alk. paper)

ISBN 978-0-8014-7983-0 (pbk. : alk. paper)

1. H1N1 influenza. 2. Epidemics-Social aspects. 3. Public healthSocial aspects. 4. Medical anthropology. I. Title.

$$
\text { RA644.I6M33 } 2014
$$

$$
\text { 614.5'18-dc23 } 2014025187
$$

Cornell University Press strives to use environmentally responsible suppliers and materials to the fullest extent possible in the publishing of its books. Such materials include vegetable-based, low-VOC inks and acid-free papers that are recycled, totally chlorine-free, or partly composed of nonwood fibers. For further information, visit our website at www.cornellpress.cornell.edu. 